\title{
Life Insurance Take-Up Rate Influencing Factors Comparison between Malaysia and Japan
}

\author{
Silvana Kardinar Wijayanti', Barry Ramsay²
}

\begin{abstract}
This study will investigate the factors that influence take-up rates within the Malaysian Life Insurance industry to discover potential opportunities and limitations. For comparative purposes, the study is modelled on Power (2013) who examined four factors affecting customer satisfaction in life insurance in Japan (product, price, customer services and procedures and documentation). This study is exploratory in nature using both secondary research and primary data from questionnaires. The main finding was "Product offerings" being the most significant variation, both an opportunity and limitation, due to the relative maturity, experience and changing trends within the insurance market of Japan, conversely growth, infancy and different dynamics in Malaysia.
\end{abstract}

Keywords: Comparison, Life Insurance, Malaysia-Japan, Product offering, Take-up rates.

Available Online: 12-08-2016

This is an open access article under Creative Commons Attribution 4.0 License, 2016.

\section{$1.0 \quad$ INTRODUCTION}

This study will investigate the factors that influence take-up rates within the Malaysian life Insurance industry to discover potential opportunities and limitations. Then comparing the results with a similar study conducted in Japan.

According to the Life Insurance Associate of Malaysia (LIAM 2014) Annual Report indicates 54\% of Malaysians are covered by life insurance plans, this includes both conventional and Islamic version (Takaful). This level falls below the Malaysian governments projected plan under the Economic Transformation Plans 2010-2020.

\footnotetext{
${ }^{1}$ Sekolah Tinggi ilmu Ekonomi Tenggarong (Tenggarong School of Economic Studies)

${ }^{2}$ Asia Pacific University, KL, Malaysia
} 


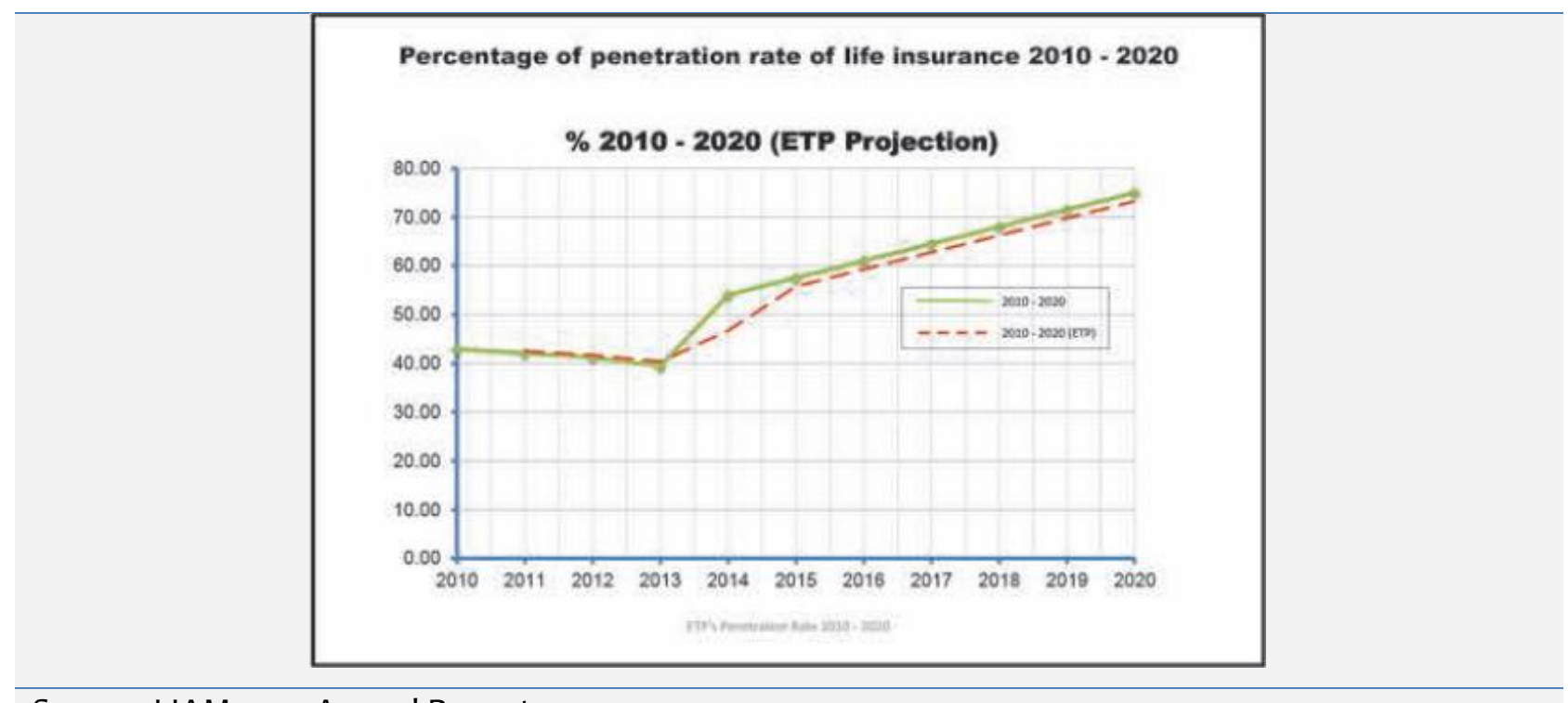

Source: LIAM 2014 Annual Report

The results of this study can assist the life insurance industry to those factors more likely to increase customer satisfaction and ultimately take-up rates.

This study was conducted with sample size of 120 subjects and using questionnaire, which is distributed to the people in Technology Park Malaysia (TPM), Bukit Jalil, Kuala Lumpur, Malaysia. For comparative purposes, the study is modelled on Power (2013) who examined four factors affecting customer satisfaction in life insurance in Japan (product, price, customer services and procedures and documentation).

The main finding was "Product offerings" being the most significant variation, opportunity and limitation, due to the relative maturity, experience and changing trends within the insurance market of Japan, conversely growth, infancy and different dynamics in Malaysia.

\subsection{PRIOR RESEARCH}

Many studies have been conducted investigating customer satisfaction in various industries Wang and Shieh, (2006); Eboli and Mazulla, (2007); Abdullah and Rozario (2009); Ojo, (2010). Studies specifically into factors that influence take-up rates in the Life Insurance Industry are limited with Power (2013) was one of the first to examining factors that influence take-up rates in the life insurance industry in Japan using "product, price" (premium), "customer service" and "procedures and documentation". Power (2013) found that Customer Service was most important followed by "Procedures and Documentation", "Price" (premium) then "Product" offered.

Whilst other studies in the Malaysian Life Insurance Industry have been undertaken such as sales agent's performance (Salleh and Kamaruddin, 2011), assessment on service quality (Ahmad and Sungip, 2008), insurance company's efficiency (Ismail, Alhabshi, and Bacha, 2011), no studies have been taken to identify factors that influence take-up rates. Therefore, this research paper will endeavour to fill this gap.

The Malaysian government has determined life insurance as one of key areas that may contribute to the country's economic growth. Thereby, the government plans to provide some stimuli to rise up the growth of the industry. Government plans to increase penetration rate of life insurance to hit $75 \%$ in 2020 by its programme, which is nationwide Economic Transformation Plan (ETP). (LIAM, 2014)

\subsection{METHODOLOGY}

This study is exploratory in nature using both secondary research and primary data from questionnaires. 
The primary research consisted of a self-administered questionnaire distributed to 120 Malaysian's (preliminary screening for foreigners) located in Technology Park Malaysia (TPM), Bukit Jalil, Kuala Lumpur, Malaysia. The location and sample size limitation is due to time and resource constraints by the researcher however can give a representative reflection if not a generalisation for the population.

The secondary research consisted of information from various sources such as journals, reference books, articles and industry. SPSS v20 is used to perform the quantitative analysis. Respondents were advised about the objective and participation was voluntary and their identity would remain confidential.

\subsection{RESULTS AND DISCUSSION}

"Product offered" are significantly different between Malaysia and Japan, in part the higher maturity, experience and volume in the Japanese market but more importantly the diversity of policies not available in Malaysia.

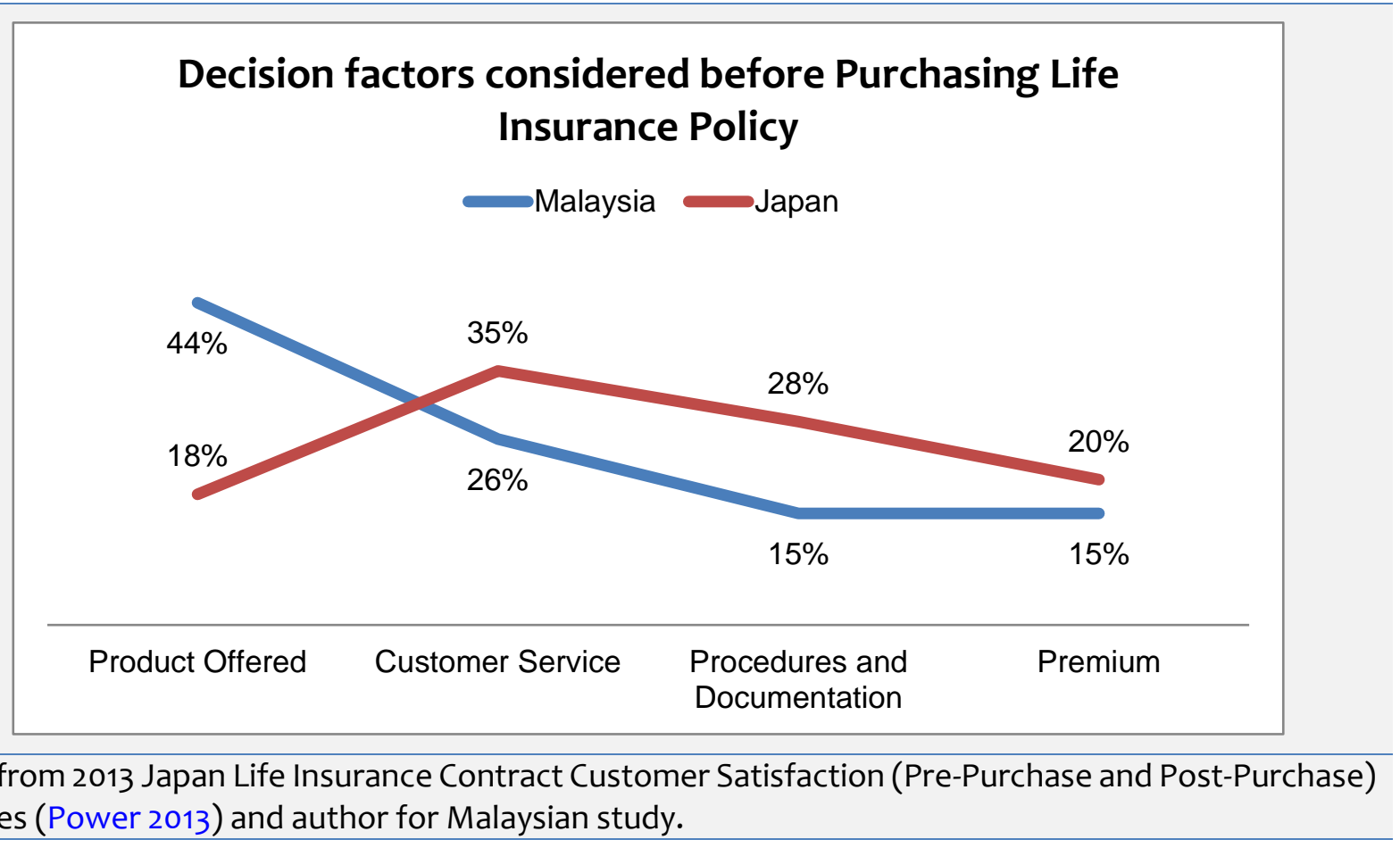

Japanese tend to use Life Insurance as an investment or superannuation for retirement (during life benefits) due in part by preferable taxation incentives that Malaysia has yet to explore. Owing to the aging Japanese population, the trend is away from death benefits towards medical benefits. Japan experienced strong sales of medical insurance and whole life insurance since 2008, these options are limited in Malaysia. (Power 2013)

"The number of policies in force increased for the sixth successive year due to the strong sales of new policies; meanwhile, the amount of policies in force has been decreasing due to the current trend of people increasing medical protection while reducing death protection." (Power 2013).

In terms of life insurance benefits, term protection and investment plans become the most preferred by people, followed by protection and saving plan. Lun (2011) supported the findings by stating that currently protection and investment plan is increasing. Most of people prefer this type of product instead of only getting protection, customers are attracted with life insurance product that allows them to gain some returns. 


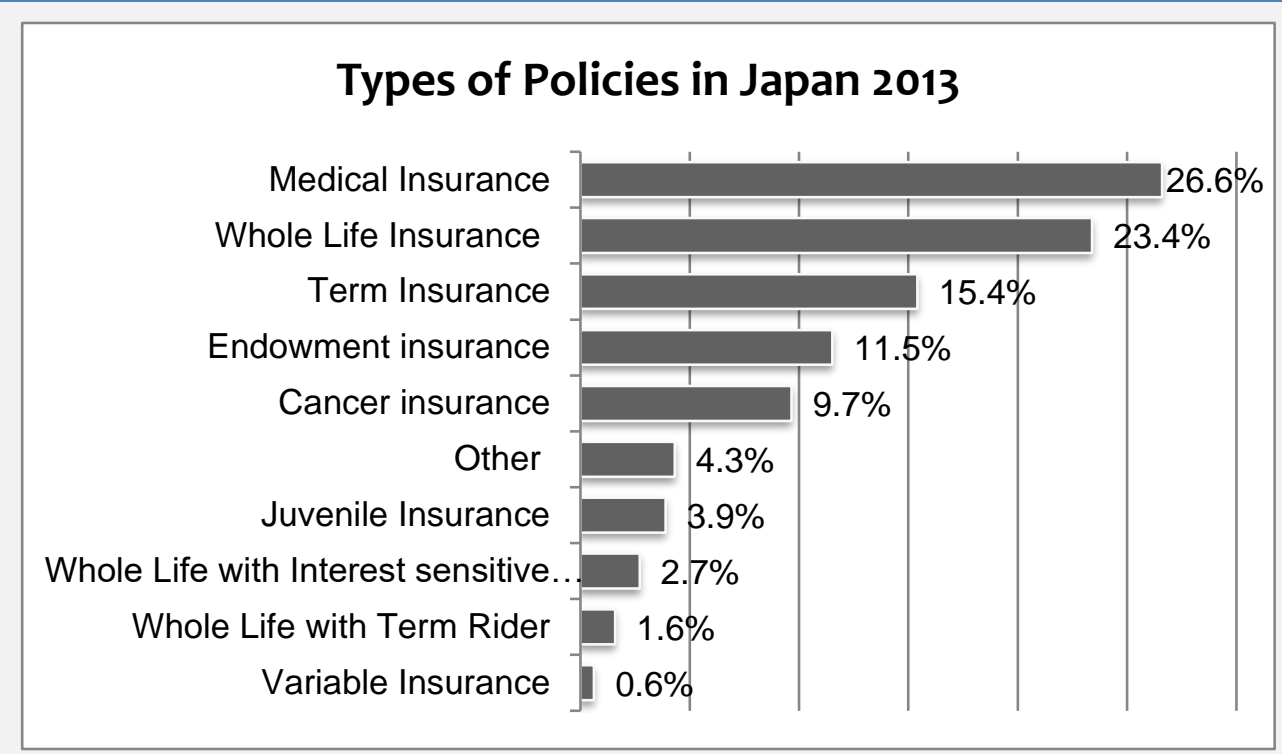

Data from 2013 Japan Life Insurance Contract Customer Satisfaction (Pre-Purchase and Post-Purchase) Studies (Power 2013)

Malaysian Life Insurance portfolio of products has increased over recent years however, still geared towards "end of life" rather than "during life" benefits and now includes the following:

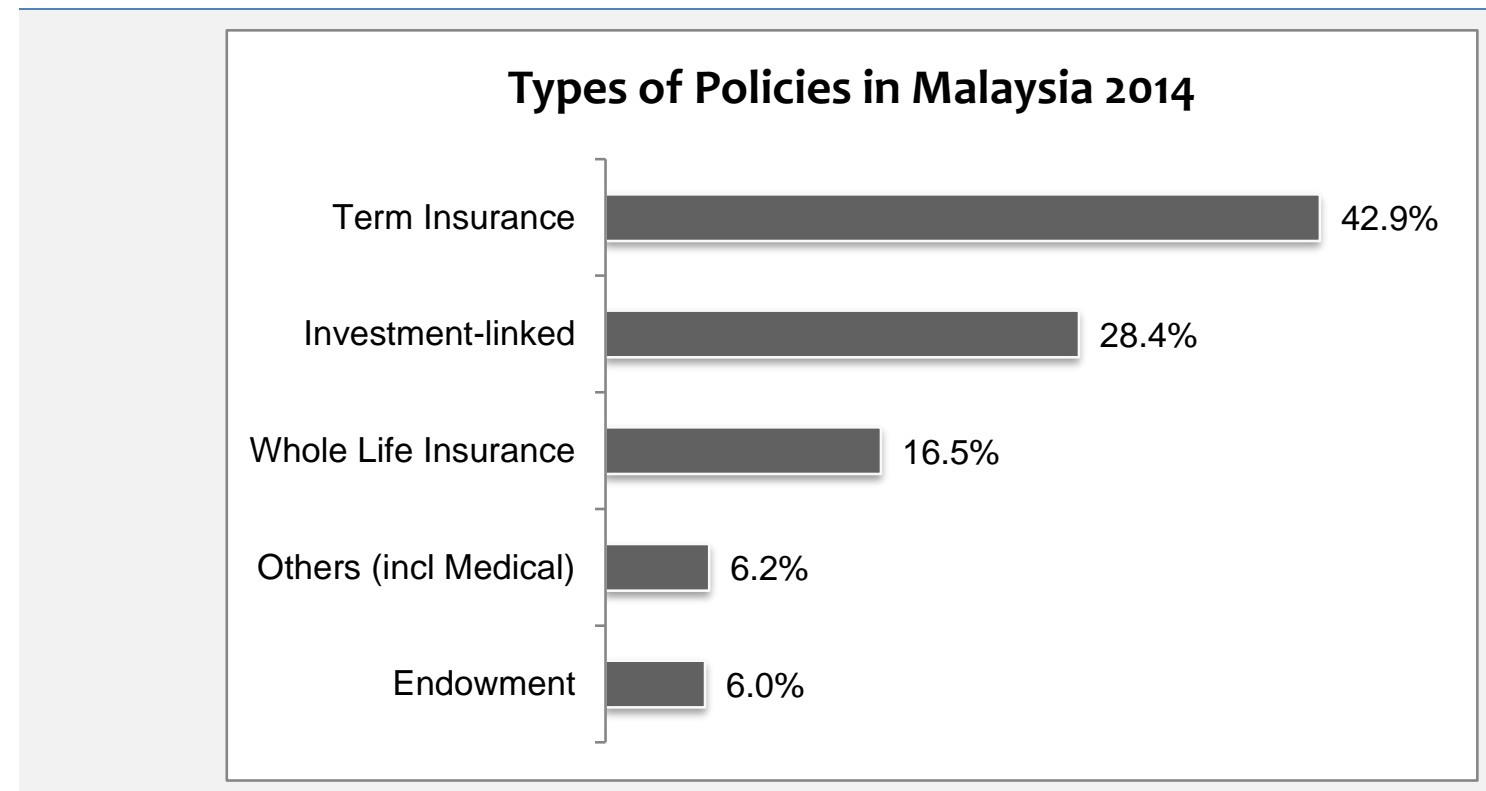

Data from Annual Insurance Statistics 2014, Bank Negara Malaysia

Furthermore, protection and saving plans become the second most preferred benefit. According to Hui (2010) in Business Times, Malaysians have tendency to save money rather than investing for insurance policy. Protection and saving plan probably can be the alternative for Malaysians to still can have savings and protection at the same time.

\subsection{CONCLUSIONS}

As the Malaysian Insurance industry matures and develops, more opportunities will arise for new innovative policies attuned to local market conditions. With a relative young work base compared to Japan, medical and slower changing cultural base is likely to put more pressure on the investment side providing taxation increases savings opportunities by government. With approximately $67.4 \%$ of the 
Malaysian population being Muslim (DSM, 2016), Takaful or Islamic insurance has prospects for further development and packaging to meet the needs of this market.

Investment linked including Islamic investment linked towards superannuation retirement plans have not been fully explored or developed in Malaysia and offers new opportunities. Medical insurance has not gained traction in Malaysia with reliance on government medical provision and not likely to change in the near future. Thus, diversity and wider ranges of product offerings have more potential to provide increase take-up rates of insurance in Malaysia.

\section{REFERENCES}

Abdullah, D. N. M. A. and Rozario, F. (2009), Influence of service and product quality towards customer satisfaction: A case study at the staff cafeteria in the hotel industry, World Academy of Science, Engineering and Technology, Vol. 53.

Ahmad, A. and Sungip, Z. (2008), An Assessment on Service Quality in Malaysia Insurance Industry, Communication of the IBIMA, Retrieved from: www.ibimapublishing.com/journals/CIBIMA/volume1 /v1n2.pdf/ [Accessed 28 April 2016].

DSM (Department of Statistics, Malaysia) (2016) Population Distribution and Basic Demographic Characteristic Report 2010 (Updated: 05/08/2011), Retrieved from: https://www.statistics.gov.my/ [Accessed 25 May 2016].

Eboli, L. and Mazulla, G. (2007), Service quality attributes affecting customer satisfaction for bus transit, Journal of Public Transportation, Vol.10, Issue 3, pp.21-34.

Hui, K.Y. (2010), Malaysia insurance market stays largely untapped, Business Times, Retrieved from: http://www.btimes.com.my/Current_News/BTIMES/articles/ges06/Article/, [Accessed 24 April 2016].

Ismail, N., Alhabshi, D.S.O. and Bacha, O. (2011), Organizational Form and Efficiency: The Coexistence of Family Takaful and Life insurance in Malaysia, Journal of Global Business and Economics, Vol.3, Issue 1, pp.122.

LIAM (Life Insurance Association of Malaysia) (2014) Annual Report 2014, Retrieved from: http://www.liam.org.my/index.php/library/annual-report/, [Accessed 28 April 2016].

Lun, S.K. (2011), Life insurance: Clear Skies Ahead, Asia Insurance Review, July, Retrieved from: http://www.asiainsurancereview.com/, [Accessed 06 May 2016].

Ojo, O. (2010), The Relationship Between Service Quality and Customer Satisfaction in the Telecommunication Industry: Evidence From Nigeria, BRAND, Vol.1, Issue 1. pp.88-100.

Power J.D. (2013) 2013 Japan Life Insurance Contract Customer Satisfaction (Pre-Purchase and PostPurchase) Study, Retrieved from: http://www.jdpower.com/ [Accessed 24 April 2016].

Salleh, F. and Kamaruddin, A.Z. (2011), The Effects of Personality Factors on Sales Performance of Takaful (Islamic Insurance) Agents in Malaysia, International Journal of Business and Social Science, Vol.2, Issue 5, pp.259-265.

Wang, I.M. and Shieh, C.J. (2006), The relationship between service quality and customer satisfaction: the example of CJCU library, Journal of Information \& Optimization Sciences, Vol.27, Issue 1, pp.193209. 